\title{
Personal style of the therapist and personality dimensions in a sample of Argentinian therapists
}

\author{
Leandro Martín Casari, ${ }^{1,2}$ Mirta Susana Ison, ${ }^{1}$ Beatriz Margarita María Gómez ${ }^{3}$ \\ ${ }^{1}$ National Scientific and Technical Research Council, City of Mendoza, Mendoza; ${ }^{2}$ Pontifical Catholic University of Argentina, City \\ of Mendoza, Mendoza; ${ }^{3}$ Aiglé Foundation, Autonomous City of Buenos Aires, Argentina
}

\begin{abstract}
The Personal Style of the Therapist (PST) is an important aspect to assess in the therapeutic process. Previous research has explored therapist's profiles and their differences according to a variety of theoretical orientations, as well as the association between these profiles and personality traits. This study aims to put together these lines of research through a cluster analysis. The specific goals were to describe the profiles of therapists with respect to the functions of the PST and personality traits; and to analyze whether the professionals' profiles and their theoretical orientations were related. The sample was comprised of 546 Argentinian therapists. The Personal Style of the Therapist Questionnaire (PST-Q) and the Big Five Inventory (BFI) were used as measuring instruments. Using the methodology of hierarchical analysis based on a cluster analysis integrating the five factors of the PST, a four-cluster solution was confirmed to be the most satisfactory. Subsequently, a cluster analysis of k-means based on the five factors of each test (PST-Q and BFI) was performed. Finally, the relationship between the clusters and theoretical orientation and years of clinical practice was assessed, rendering positive outcomes. The results are discussed based on previous research studies and the significance of studying the therapist's personal variables and their connection with psychotherapy efficacy.
\end{abstract}

Key words: Personal style of the therapist; Psychotherapy; Cluster analysis; Personality.

Correspondence: Leandro Martín Casari, National Scientific and Technical Research Council, City of Mendoza, Mendoza, Argentina.

Tel./Fax: +549.0261 .5244316 .

E-mail: leandromartincasari@gmail.com

Citation: Casari, L. M., Ison, M. S., \& Gómez, B. M. M. (2019). Personal style of the therapist and personality dimensions in a sample of Argentinian therapists. Research in Psychotherapy: Psychopathology, Process and Outcome, 22(2), 292-307. doi: 10.4081/ripppo.2019.362

Contributions: LMC oversaw data collection and results analysis; MSI and BG participated in the discussion and review of the full text.

Conflict of interest: the authors declare no potential conflict of interest.

Funding: Multiannual Research Project [PIP] $\mathrm{N}^{\circ}$ $11220170100664 \mathrm{CO}$ - CONICET.

Received for publication: 20 December 2018.

Revision received: 21 March 2019.

Accepted for publication: 26 April 2019.

This work is licensed under a Creative Commons Attribution NonCommercial 4.0 License (CC BY-NC 4.0).

${ }^{\circ}$ Copyright: the Author(s), 2019

Licensee PAGEPress, Italy

Research in Psychotherapy:

Psychopathology, Process and Outcome 2019; 22:292-307

doi:10.4081/ripppo.2019.362

\section{Introduction}

Understanding how psychotherapy works requires multiple perspectives (Lambert, 2013; Wampold \& Imel, 2015), one of which entails studying the main participants involved in the process: the client and the therapist. Exploring the therapist's variables is an important research topic (King, Orr, Poulsen, Giacomantonio, \& Haden, 2017; Schiefele et al., 2017); in accordance with metaanalyses, the percentage attributed to the therapist effectiveness in psychotherapy ranges between 5 and $9 \%$ in meta-analyses (Baldwin \& Imel, 2013; Miller, Hubble, Chow, \& Seidel, 2013). Variability among psychotherapists constitutes a key factor in terms of outcomes (e.g., Del Re, Flückiger, Horvath, Symonds, \& Wampold, 2012; Dinger, Zimmermann, Masuhr, \& Spitzer, 2017; Schöttke, Flückiger, Goldberg, Eversmann, \& Lange, 2017).

Furthermore, therapist variables relevant to clinical practice may be divided into demographic and professional. The professional variables include their experience (e.g., Tschuschke et al., 2015; Walsh, Roddy, Scott, Lewis, \& Jensen-Doss, 2018; Zimmermann, Rubel, Page, \& Lutz, 2017), their academic specialization (Prout \& DeBerard, 2017), and their training, either at a technical or relational level (e.g., Del Re et al., 2012; Roos \& Werbart, 2013). The personal or demographic variables include the therapists' attachment style (e.g., Parpottas \& DraghiLorenz, 2015; Steel, Macdonald, \& Schroder, 2018), their self-efficacy (Zimmermann et al., 2017), their interpersonal skills (e.g., Anderson, Crowley, Himawan, Holm- 
berg, \& Uhlin, 2016; Niessen-Lie, Havik, Høglend, Monsen, \& Rønnestad, 2013; Schöttke et al., 2017; Watson, Steckley, \& McMullen, 2014) and sex (Prout \& DeBerard, 2017).

The Personal Style of the Therapist (PST) has been positively connected with psychotherapy outcomes (Botella \& Corbella, 2005; Hermosa-Bosano, 2010; Malik et al., 2002; Moya-Cortés, 2015).

The PST has been defined as a set of singular conditions which lead a therapist to operate in a way in his/her work. This refers to the normal characteristics which each therapist imprints on his work because of his peculiar way of being, regardless of the work focus he uses, and the specific requirements demanded by his intervention (Fernández-Álvarez, García, \& Shreb, 1998, p. 352).

According to Beutler, Machado, and Alstetter Neufeldt (1994) the PST depends on three factors: professional status in the society, lifestyle, and forms of communication mostly used. The third factor acquires the greatest relevance because it is the most idiosyncratic and compromises the fundamental stylistic actions with which the PST shapes the applications of a specific technique (Fernández-Álvarez et al., 1998, p. 352).

Although relatively stable, it also changes over time, especially due to the therapist's training, modifications in the working context, development factors (therapist's age), and other personal circumstances of the therapist's life (e.g., traumatic experiences) (Fernández-Álvarez, García, Lo Bianco, \& Corbella-Santoma, 2003).

The construct is made of functions that work in unison imprinting a personal style of exercising the role of therapist with the patients. A discussion about the functions of the PST has taken place in the last twenty years (Fernández-Álvarez \& García, 1998). In the first ten years (1998-2008), interest was given to studying how the theoretical and empirical aspects are related (Casari, Ison, \& Gómez, 2018). Seven different functions of PST have been defined over the years (Corbella-Santoma, Botella, Fernández-Álvarez, Saúl, \& García, 2009), but only those with enough empirical support across the studies of construct validity (exploratory and confirmatory) have remained. The definition of the functions, then, has an empirical foundation, which is why there is an overlap in the theoretical and empirical definitions.

The strongest consensus suggests that the PST stands for a model of five bipolar functions occurring at every therapeutic act (Fernández-Álvarez et al., 2003), namely: i) Instructional: related to the degree of flexibility to establish the rules of the therapeutic setting, which ranges from flexible to rigid; ii) Expressive: actions carried out by the therapist to ensure emotional communication with the patient as a key component of empathy, and where polarities range from emotional closeness to emotional distance; iii) Engagement: the therapist's degree of commitment to the work and the place that work holds in his or her life, where polarities range from greater degree to lesser degree; iv) Attentional: the ways of gathering therapeutic information, categorized as broad-focused or narrow-focused; v) Operational: related to the therapist's preference to act spontaneously or according to a plan, following the procedures established in a manual or the steps of different techniques.

Beyond this discussion, several empirical research studies have explored the relationship between the PST and personality or professionals' factors.

For example, different studies have established the relation between personality and the PST (Corbella-Santoma et al., 2007; Estrada-Aranda, 2014; Hermosa-Bosano, 2010). In fact, the PST is described as ...the normal characteristics imprinted by each therapist on his/her work as a result of his/her specific way of being (Fernández-Álvarez et al., 1998, p. 352). Some authors have even come to potentially consider the PST as a personality style (García \& Fernández-Álvarez, 2007), so studying the possibility of predicting PST functions through personality factors acquires a new significance (Quiñones-Bergeret, MelipillánAraneda, \& Ramírez-Azócar, 2010).

A direct influence of personality traits on PST is highly expectable. For example, Genise (2015) found significant positive correlations between personality dimensions of therapists (assessed through the Big Five Inventory) and PST functions, specifically between the Expressive function and the Extraversion dimension, and between PST technical functions (Attentional and Operational) and Neuroticism (Genise, 2015; Genise \& García, 2016).

Additionally, professional variables studied in earlier PST research studies include: the type of clinical patients and its influence on the PST, duration of treatment, type of therapy (individual, couples, family, etc.), years of professional experience and professional training, among others (Casari, Ison, Albanesi, \& Maristany, 2017; Castañeiras, García, Lo Bianco, \& Fernández-Álvarez, 2006; Castañeiras, Ledesma, García, \& Fernández-Álvarez, 2008; Corbella-Santoma et al., 2009; Da Silva, Tellet, Fernández-Álvarez, \& García, 2006; Gómez et al., 2011; Grzona, Muñoz, Casari, \& Videla, 2016). However, most of the previous research in this topic has focused on studying the main differences among the theoretical orientation used by therapists (Casari et al., 2018). At the beginning, the PST was regarded as being independent from the theoretical framework (Fernández Álvarez et al., 2003), but empirical research studies have shown that this variable is highly sensitive to differences in PST functions (Casari et al., 2018). For example, Silva-Palma and Guedes-Gondim (2016) pointed out that psychoanalytic therapists are mostly inclined to use broad-focused attention, while cognitive therapists are typically more structured in their therapeutic interventions. The question that remains unanswered is whether the adherence to a theoretical orientation influences the PST or if it is the professional's personality that leads him or her to choose a technical orientation (Cariaga-Siracusa \& Casari, 2014; 
Ciorbea \& Nedelcea, 2012; García \& Fernández-Álvarez, 2007; Heinonen \& Orlinsky, 2013).

Another professional variable that has been studied is the years of clinical experience, understood in PST research as the number of years of professional practice (Castañeiras et al., 2006). For example, in professionals with more experience, the Attentional function is broader (not narrow) and the Operative function tends to be more spontaneous (Castañeiras et al., 2006; Da Silva et al., 2006). However, other studies have not found significant results between PST functions and the years of professional experience (Castañeiras et al., 2008; Moya-Cortés, 2015). This difference may be attributable to how this variable was measured: the first two studies used categories (beginner and expert therapists, depending on the number of practicing years), whereas the last studies used the number of years (measured by means of a correlational statistical analysis).

The PST has been mostly studied in terms of an external variable (personal or professional), however several studies have explored the profiles of therapists without taking independent variables into account, using the methodology of cluster analysis (Fernández-Álvarez, Castañeiras, García, Gómez, \& Fernández-Álvarez, 2017; Quiñones-Bergetet et al., 2010).

Quiñones-Bergetet et al. (2010) studied the profiles of therapists in a sample of 92 therapist from Chile. First, a hierarchical cluster analysis was performed using Ward's method and squared Euclidean distance as a means of measuring distance among the data. Before that, the four factors of the PST (the exploratory factor analysis in Chile found four factors instead of five) had been standardized (z-score). In the dendrogram two different profiles were found, with a distribution of $42.2 \%$ and $57.6 \%$. After this first analysis, a non-hierarchical cluster analysis based on the method of k-means was performed. The initial center for building this cluster was the average scores of these two clusters on the four factors of the PST Questionnaire. The distribution was confirmed, and the therapists were grouped into two different clusters: a more inflexible one, from a therapeutic point of view; and one where motivational and emotional skills were more developed (Castañeiras et al., 2008), characterized by the therapists' emotional closeness and commitment to the task (Quiñones-Bergetet et al., 2010). Additionally, the authors found significant differences in three of the four functions of the PST: Emotional Expression and Engagement (higher in Cluster 2), and Instructional (higher in Cluster 1).

Fernández-Álvarez et al. (2017) studied whether there was any relation between therapists' profiles and verbal communication (type and frequencies of questions during the session). In the study, the sample was comprised by 20 Argentinian therapists, applying a hierarchical cluster analysis with Ward's method and squared Euclidean distance as a means of measuring distance among the data. The number of clusters was based on the dendrogram and three different profiles of therapists were found: the first one, named directive by the authors, is considered highly technical in their approach (narrow-focused attention and a preference for planned interventions); the second group named non-directive by the authors, is characterized by broad-focused attention and a preference for spontaneous interventions; while the third cluster shows an average between both groups. These characteristics were confirmed by means of an analysis of variance (ANOVA), where the Attentional and the Operative functions showed significant differences among the clusters (Clusters 1 and 2).

Stating the current research findings, the aim of the present study was to examine the relation between PST function, therapists' personality profile and their theoretical orientation in a sample of 546 therapists. Our research had descriptive-correlational hypotheses, so our expectations were to find an association between the variables by conducting an unprecedented study in the tradition of PST: a cluster study with a larger sample and adding personality variables.

The specific goals were: i) to describe therapists' profiles based on PST functions and personality dimensions; ii) to analyze if these profiles were related to the professionals' theoretical approach; iii) to analyze if these profiles are related to years of clinical practice.

The hypotheses were: i) Each cluster has at least one factor with extreme scores in PST functions and personality factors (none cluster will be formed exclusively by PST functions or personality factors in extreme values); ii) The clusters are related to the professional's theoretical approach (at least one cluster is associated with a majority representation of a theoretical approach); iii) The PST functions and the personality factors are correlated with the years of clinical practice.

\section{Methods}

\section{Participants}

Our purposive sample (Hernández-Sampieri, Fernández-Collado, \& Baptista-Lucio, 2014) consisted of 546 Argentinian therapists, whose main characteristics (demographic and professional) are shown in Table 1.

\section{Measures}

\section{Demographic and professional questionnaire}

The demographic and professional questionnaire (Fernández-Álvarez et al., 2003) is the first part of the PST-Q and it addresses demographic variables, such as age and sex, and professional aspects like specialization degree (e.g., Master's degree), patient's age (e.g., children or adolescents), theoretical orientation (e.g., cognitive-behavioral therapy), treatment duration (e.g., short-term, long-term), type of psychotherapy (e.g., individual, group therapy) and context of practice (e.g., independent, private practice). 


\section{Personal Style of the Therapist Questionnaire}

The PST-Q (Fernández-Álvarez et al., 2003) was designed as a self-report measure to explore the functions of the PST (Corbella \& Botella, 2004). Its fundamentals are the following ones:

- The Generic Model of Psychotherapy (developed by Orlinsky, Grawe, \& Parks, 1994), where the therapist's variables include socio-demographic status, vital situation and personal style. For the authors, personal style refers to the traits related to the therapist's personality that have an influence in the therapeutic relationship and psychotherapy outcomes.

- The classification of therapists' variables provided by Beutler and colleagues (1994) in a previous edition of the Handbook of Psychotherapy and Behavior Change, the authors divide the therapist's variables in four axes: objective and subjective characteristics, and specific and general traits. The personal style of a ther-

Table 1. Demographic and professional characteristics of the sample $(\mathrm{N}=546)$.

\begin{tabular}{|c|c|c|}
\hline \multicolumn{3}{|c|}{ Frequencies } \\
\hline \multirow[t]{2}{*}{ Sex } & Female & $456(84.1 \%)$ \\
\hline & Male & $87(15.9 \%)$ \\
\hline \multirow[t]{2}{*}{ Age (years) } & $\mathrm{M}(\mathrm{SD})$ & $32.76(8.15)$ \\
\hline & Range & $23-68$ \\
\hline \multirow[t]{2}{*}{ Years of professional experience } & $\mathrm{M}(\mathrm{SD})$ & $5.55(6.53)$ \\
\hline & Range & $0-43$ \\
\hline \multirow[t]{4}{*}{ Specialization degree } & University degree & $285(52.2 \%)$ \\
\hline & Graduate specialization & $225(41.2 \%)$ \\
\hline & Master's degree & $32(5.9 \%)$ \\
\hline & $\mathrm{PhD}$ & $4(.7 \%)$ \\
\hline \multirow[t]{4}{*}{ Patients' age } & Children and adolescents & $119(21.8 \%)$ \\
\hline & Adults & $296(54.2 \%)$ \\
\hline & Elders & $2(0.4 \%)$ \\
\hline & More than one option & $129(23.6 \%)$ \\
\hline \multirow[t]{4}{*}{ Type of therapy } & Individual & $399(73.1 \%)$ \\
\hline & Group & $16(2.9 \%)$ \\
\hline & Family & $33(6 \%)$ \\
\hline & More than one option & $98(17.9 \%)$ \\
\hline \multirow[t]{6}{*}{ Theoretical orientation } & Cognitive-Behavioral Therapy & $65(11.9 \%)$ \\
\hline & Humanistic-Existential and Gestalt Therapy & $44(8.1 \%)$ \\
\hline & Integrative Therapy & $173(31.7 \%)$ \\
\hline & Psychoanalysis & $185(33.9 \%)$ \\
\hline & Systemic Therapy & $57(10.4 \%)$ \\
\hline & Other & $22(4 \%)$ \\
\hline \multirow[t]{4}{*}{ Context of the practice } & Independent & $256(46,9 \%)$ \\
\hline & Private practice (e.g., private clinics) & $122(22.3 \%)$ \\
\hline & Public practice (e.g., public hospitals) & $127(23.3 \%)$ \\
\hline & More than one option & $41(7.5 \%)$ \\
\hline \multirow[t]{4}{*}{ Treatment duration } & Short-term (less than 6 months) & $206(37.7 \%)$ \\
\hline & Intermediate (6 months -2 years) & $294(53.8 \%)$ \\
\hline & Long-term (more than 2 years) & $32(5.9 \%)$ \\
\hline & More than one option & $14(2.6 \%)$ \\
\hline
\end{tabular}

M, Mean; SD, Standard deviation. 
apist is an objective state, highly stable across time, and having an influence in any technique or procedure applied.

Originally, the items designed to explore the functions of the PST were were established by three expert psychotherapists (Fernández-Álvarez et al., 2017). The first version of the PST-Q featured 48 items (Fernández-Álvarez \& García, 1998). To this day, there has been no study of content validity by a panel of experts (Casari et al., 2018). A few years after the original publication, a 36item version was created to study construct validity by means of exploratory factor analysis (Fernández-Álvarez et al., 2003). Currently, there are five bipolar functions (Instructional, Expressive, Engagement, Attentional, Operational or Instrumental Implementation).

\section{Instructional}

The various behaviors defined by the therapist in order to establish and regulate the setting of the therapy (Fernández-Álvarez et al., 2003, p. 188). It includes the rules that will operate throughout the therapy, such as fees, schedules, location for the sessions, and all actions concerning the therapeutic contract. The polarities range from flexibility to rigidity. Some examples are: I am fairly relaxed about my working hours or I often see patients outside of the office setting.

\section{Expressive}

Actions carried out by the therapist to ensure emotional communication with the patient. It is one of the central aspects in empathy (Fernández-Álvarez et al., 2003, p. 188). The main aspect is the communication distance that each therapist prefers to establish with his or her patients, the depth of emotional exchange with the patient, the level of tolerance towards exposing his or her own emotional moods or the patient's reactions. The polarities range from distance to closeness, for example: If something irritates me during a session, I can show it.

\section{Engagement}

The set of explicit and implicit behavior connected with the therapist's commitment to his task in general and, in particular, to his patients (Fernández-Álvarez et al., 2003, p. 199). It is also related to the importance of the job in the context of his or her life. The polarities range from low degree to greater degree, for example: $M y p a-$ tients' problems have little influence on my personal life.

\section{Attentional}

Related to the therapist's way of seeking information, it is closely associated with the interventions, mainly devoted to asking and listening. The polarities range from broad-focused to narrow-focused. Broad focus is related to a passive way, like a radar waiting for some key information to be detected. Narrow focus implies looking for information actively, asking for specific information. A few examples would be: I prefer to be aware in advance of what I should pay attention to in a session or I prepare to listen with free-floating attention right from the start of a session.

\section{Operational or Instrumental Implementation}

Actions directly connected with specific therapeutic interventions (Fernández-Álvarez et al., 2003, p. 119), but it does not refer to the techniques. It is the way in which the therapist chooses to intervene and have an impact on the patient. The polarities range from spontaneous to planned, as in: As the therapist, I prefer to let the patient know what will happen in each session or I place little value on directive treatments.

The 36 statements are individually responded by the therapist according to his or her level of agreement, using a Likert-type scale ranging from 1 (strong disagreement) to 7 (strong agreement). The final score of the functions is obtained by adding the value of all items that belong to each function, for example, the Attentional function has 6 items, so the final score is the outcome of this addition. However, some items have negative score, and they must be added in an inverse way (for example, if the subject chose 7 , the item add as 1). There are no reference scores to use as a cut-point off. The PST-Q has only been used for research purposes and may only be applied to therapists, although some studies present students doing clinical practice (Estrada-Aranda, 2014). Several versions of the PST-Q are available (Casari, Morán, \& Ison, 2017); the one used in this study was the original 36 -item questionnaire.

The PST-Q showed satisfactory psychometric properties. Fernández-Álvarez et al. (2003) analyzed the validity of the instrument through an exploratory factor analysis in a sample of 366 Argentinian therapists, which resulted in four factors accounting for $40 \%$ of the variance: Attentional-Operational function, engagement function, expressive function, and instructional function. Nonetheless, the authors considered a five-factor structure appropriate due to the theoretical differences between the two functions: Attentional and Operational. Reliability levels analyzed using Cronbach's alpha were acceptable: Attentional $(\alpha=.80)$, Operational $(\alpha=.76)$, Instructional $(\alpha=.69)$, Engagement $(\alpha=.75)$, Expressive $(\alpha=.75)$. The values were practically similar for the current sample: Attentional $(\alpha=.71)$, Operational $(\alpha=.70)$, Instructional $(\alpha=.72)$, Engagement $(\alpha=.71)$, Expressive $(\alpha=.73)$. Castañeiras et al. (2008) ran a confirmatory factor analysis with a sample of 461 Argentinian therapists and found that the theoretical model offers an adequate adjustment index.

\section{Big Five Inventory}

A translation by Castro-Solano (2005) of the Big Five Inventory (BFI) developed by John (1990) was used. 
Comprised of 44 items, the BFI seeks to assess the big five personality dimensions: Neuroticism (emotional stability), Extraversion (sociability and dynamism), Openness to Experience (creativity and esthetic sensitivity), Agreeableness (willingness to help) and Conscientiousness (commitment to obligations).

The items present a list of characteristics (statements) often used to describe people. Subjects must indicate their level of agreement with each statement using a Likerttype scale ranging from 1 (strong disagreement) to 5 (strong agreement).

Psychometric properties were analyzed in a sample comprising 639 people from Buenos Aires (Castro-Solano, 2005). An exploratory factor analysis was then carried out to analyze the construct validity, which showed a five-factor structure that explained the $45 \%$ score variance. It was then concluded that the items were grouped into the factors as expected. Reliability levels also proved satisfactory using Cronbach's alpha analysis: Extraversion $(\alpha=.68)$, Agreeableness $(\alpha=.66)$, Conscientiousness $(\alpha=.70)$, Neuroticism $(\alpha=.74)$ and Openness to Experience $(\alpha=.77)$. Similar or slightly superior reliability values were found in the current sample: Extraversion $(\alpha=.76)$, Agreeableness $(\alpha=.65)$, Conscientiousness $(\alpha=.77)$, Neuroticism $(\alpha=.75)$ and Openness to Experience $(\alpha=.80)$.

\section{Procedure}

The global sample consisted of two subsamples of therapists. In both subsamples, informed consent was attached to the protocol. The informed consent form required the professional's signature, with information on the purpose of the research, data confidentiality and the main researcher's contact details.

The first subsample was recruited between July and November 2017 at public services and private clinics, after the authorization from the hospital. A total of 400 questionnaires were delivered to the practitioners, 233 were completed (response rate: $58.25 \%$ ).

The second subsample was recruited via e-mail, recruiting the therapists in databases of professional websites. Between February and August 2018, 500 electronic questionnaires were sent, 313 of which were filled out and returned (response rate: $62.6 \%$ ).

Only one subject failed to specify his or her theoretical technical orientation. However, this subject was contacted, and the missing information was filled out correctly.

\section{Data analysis}

The data were processed using the Statistical Package for Social Science (SPSS) software, version 24.0. To accomplish the first aim, a cluster analysis was performed. This decision was arrived at since this multivariate technique is less restrictive than others in its assumptions (it is not influenced by the requirements of normalcy and homoscedasticity and it allows categorical variables) and makes it possible to group the cases in order to obtain maximum homogeneity in each group and the greatest difference between the groups, something that is unknown a priori (Everitt, Landau, Leese, \& Stahl, 2011; Manly, 2005). The recommended approach is two-stage clustering, with hierarchical and k-means procedures used in tandem (Balijepally, Mangalaraj, \& Iyengar, 2011). The k-means method is a widely used tool in data mining given its efficiency in clustering large databases to present it in the form that is needed for the specific task, where the number of clusters must be set in advance (Mihai \& Mocanu, 2015). The hierarchical method proves ideal to promptly detect the optimal number of clusters in the data, based on the similarity between cases (Everitt et al., 2011).

Regarding the aspect of an optimal sample size to run a cluster analysis, there is no consent among the authors, since sample size could be related to the number of variables and population size (Dolnicar, 2002). Wedel and Kamakura (2000) suggest using a sample larger than 500 units to carry out a k-means analysis, as was the case for this research. Calculating a representative sample proves crucially important. In Argentina, for example, more than 98,000 psychologists are currently working (Alonso \& Klinar, 2016), so a representative sample should comprise a minimum of 383 subjects considering a $5 \%$ margin of error and a $95 \%$ confidence interval. Consequently, this study offered a representative sample of the population.

After the cluster analysis, a chi-squared test was used to explore the second aim. We reported the observed and expected frequencies and used Cramer's V as a statistical measure of effect size.

For the last aim, the Pearson correlation coefficient was used to find out whether there was any relation between the factors of PST and BFI and the years of clinical practice.

\section{Results}

Before performing the cluster analysis, the relation between the variables of the measures PST-Q and BFI (Table 2) was studied, since one of the requirements to carry out cluster analysis is the absence of multicollinearity among the variables (Balijepally, Mangalaraj, \& Iyengar, 2011). As a result, PST functions showed at least one significant correlation with personality factors. This was true for personality factors and PST functions as well (all of them having at least one significant correlation except for Agreeableness). Most of the correlations were negative: only $12 \%$ ( 3 of the correlations) were positive, which may suggest a certain independence of the variables. Apart from that, all the values of the correlation (effect size) were small $(r<.30)$ (Aron \& Aron, 2001), which is why it can be assumed there were no issues concerning multicollinearity since the correlations were not high.

Based on the cluster analysis, the best data clustering was determined according to the five factors of the PST$\mathrm{Q}$ and the BFI. 
Firstly, to identify the optimal number of clusters to classify the sample in the PST, a hierarchical cluster analysis was carried out using Ward's method and the squared Euclidean distance to measure the distance among the data. PST-Q scores had been previously standardized to control the incidence of the factors bearing the greatest variability in the final cluster solution. The analysis revealed that a four-cluster solution was the most satisfactory one. Secondly, a k-means clustering analysis took place regarding the standardized scores from PST-Q and BFI factors (Figure 1 and Table 3).

To find out the specific differences between cluster variables, an ANOVA with the mean scores (Table 4) was performed. Significant outcomes were found in all variables $(P<.001)$. In most cases, the effect size was large $\left(\eta^{2}>.25\right)$, while others were medium $\left(\eta^{2}>10\right)$ (Cohen, 1998).
The therapists in Cluster 1 revealed the highest scores in Attentional and Operative functions of PST, the lowest scores in Extraversion, Agreeableness, Openness to Experience, and the highest ones in Neuroticism. These professionals were characterized by their attentional narrow-focus and their preference for structured treatment. They were described as loners, reserved, egocentric and hedonistic, in addition to being more inclined to psychological vulnerability, showing a rather conservative profile.

The therapists in Cluster 2 showed no prevalence of PST functions, but they displayed extreme scores across all personality factors, the highest ones being Extraversion, Agreeableness, Conscientiousness, and Openness to Experience. Cluster 2 evidenced the lowest value in Neuroticism. Based on these characteristics, this cluster included more energetic therapists, who were willing to help

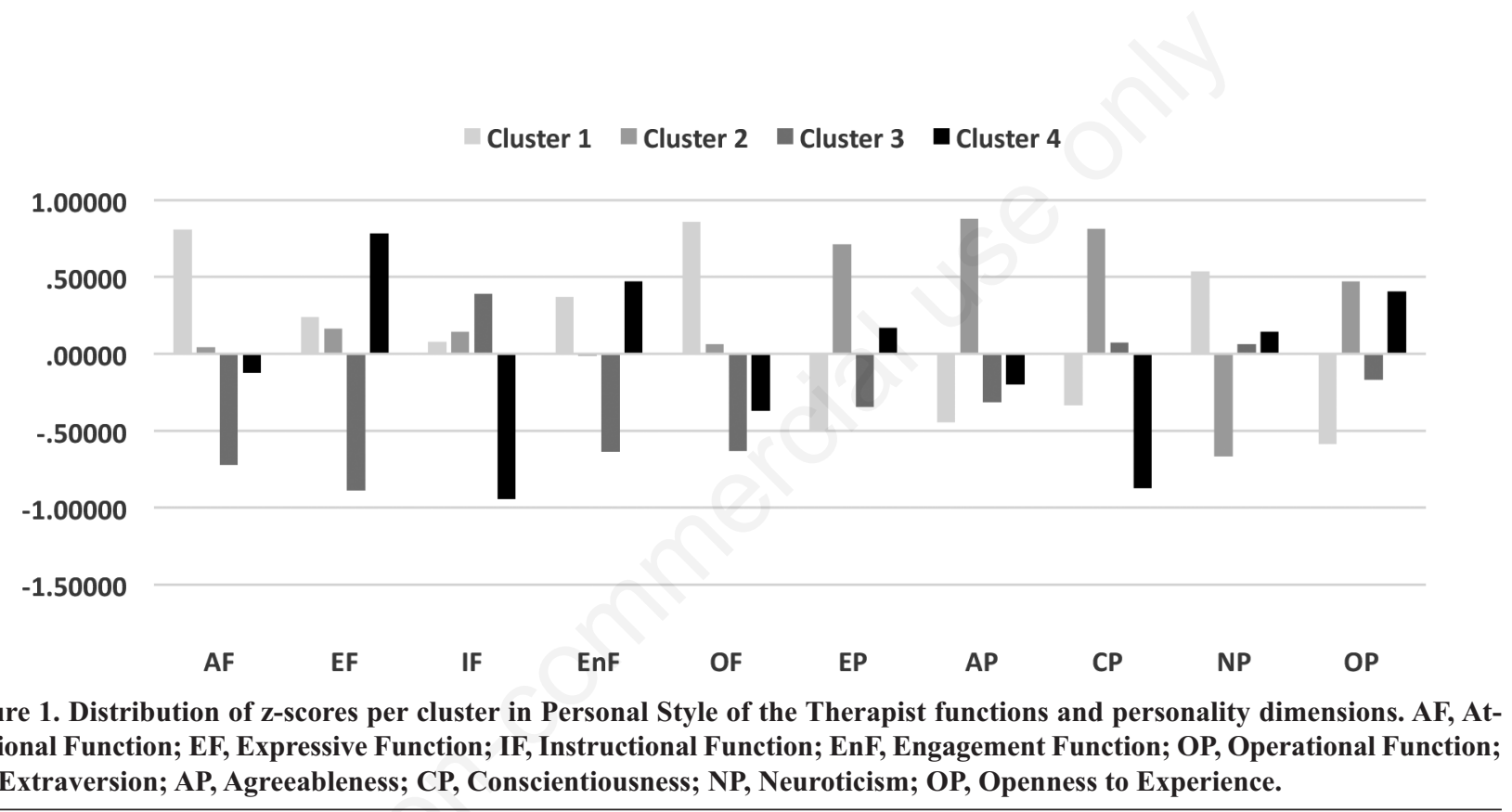

Table 2. Correlations between Personal Style of the Therapist and Big Five Inventory ( $N=546)$.

\begin{tabular}{|c|c|c|c|c|c|c|}
\hline PST/BFI & & Extraversion & Agreeableness & Conscientiousness & Neuroticism & Openness to Experience \\
\hline \multirow[t]{2}{*}{ Attentional Function } & $r$ & -.01 & -.03 & -.09 & .01 & -.05 \\
\hline & $\mathrm{P}$ & .71 & .40 & .02 & .75 & .16 \\
\hline \multirow[t]{2}{*}{ Expressive Function } & $r$ & .16 & .04 & -.10 & .01 & .08 \\
\hline & $\mathrm{P}$ & .0001 & .33 & .01 & .70 & .05 \\
\hline \multirow[t]{2}{*}{ Instructional Function } & $r$ & -.01 & -.03 & .21 & -.02 & -.04 \\
\hline & $\mathrm{P}$ & .76 & .41 & .0007 & .61 & .26 \\
\hline \multirow[t]{2}{*}{ Engagement Function } & $r$ & -.01 & .006 & -.09 & .17 & -.01 \\
\hline & $\mathrm{P}$ & .69 & .88 & .02 & .0008 & .76 \\
\hline \multirow[t]{2}{*}{ Operational Function } & $r$ & .01 & -.04 & -.01 & -.009 & -.10 \\
\hline & $\mathrm{P}$ & .76 & .27 & .72 & .81 & .01 \\
\hline
\end{tabular}

Numbers in bold and italics are statistically significant. PST, Personal Style of the Therapist; BFI, Big Five Inventory. 
and showed commitment to their academic and professional achievements, in addition to being creative and emotionally stable.

Cluster 3 presented therapists with the highest scores in the Instructional function, but the lowest ones in the remaining PST functions: Attentional, Expressive, Engagement, and Operational. Additionally, they showed no prominent personality factors. This set of professionals preferred a passive approach to information search and showed some distance in terms of the therapeutic bond. They also evidenced certain rigidity to establish the therapeutic setting, had low levels of commitment to their work and a tendency to choose spontaneous interventions. With no extreme personality traits either, this cluster centralized the largest representation of PST functions.

Finally, the PST profile of the therapists in Cluster 4 was characterized by the highest scores in the Expressive and Engagement functions, but the lowest in Instructional and Conscientiousness. These scores mean therapists were more empathetic and committed to their patients, showing flexibility in terms of psychotherapy rules. They were further described as slightly hedonistic in their personality style.

In conclusion, the first hypothesis, each cluster has at least one factor with extreme scores in PST functions and personality factors, must be rejected it because some clusters revealed no characteristic representation of PST functions or personality factors (e.g., Cluster 3).

To achieve the second aim, the relation between the clusters and the theoretical orientations was analyzed. This professional variable has been studied the most in PST research, having shown high sensitivity to differences among therapists' styles (Casari et al., 2018).

Set as independent, this variable was analyzed to evaluate its ability to symmetrically differentiate the therapists belonging to various theoretical orientation in the four clusters that had been previously found. Consequently, a chi-square test was applied (Table 5), showing significant results: $\chi^{2}(15)=155.43, \mathrm{P}<.001$. The association was moderate: Cramer's $V>.30$ (Cohen, 1998).

Psychoanalytic therapists seemed to be mostly concentrated in Cluster 3 (57\%), cognitive-behavioral professionals in Cluster 1 (51\%), while Cluster 4 encompassed $39 \%$ of the humanistic-existential and Gestalt therapists. Integrative therapists, on their part, were represented in Clusters 1 and $2(65 \%)$, where a similar concentration was also evident for systemic therapists (67\%). Despite the positive results from the chi-squared test, the disproportionate number of therapists per theoretical framework should be considered: $65.7 \%$ were represented by integrative and psychoanalytic therapists.

These results confirmed the second hypothesis: The clusters are related to the professional's theoretical approach, as statistical associations between the cluster and theoretical orientation variables were revealed.

Finally, the influence of other professional variable, the years of clinical experience, was studied. To achieve this aim, Pearson correlation coefficient was used (Table 6).

Based on these results, the third hypothesis was confirmed: The clusters are related to the years of clinical practice. In fact, all the personality factors showed positive significant correlations with the years of professional practice, except for Neuroticism, which showed a significant negative correlation.

\section{Discussion}

Psychotherapy practice implies a degree of variability in the way therapists outline and operate their interventions, the therapeutic setting, the emphasis placed on the therapeutic alliance, etc. based on their style (Heinonen,

Table 3. Standardized scores of Personal Style of the Therapist functions and personality dimensions per clusters (N=546).

\begin{tabular}{lcccc}
\hline PST and BFI factors & \multicolumn{4}{c}{ Center of final clusters } \\
\hline Attentional Function & $.144=26.37 \%)$ & $2(151=26.37 \%)$ & $3(153=28.02 \%)$ & $4(98=17.94 \%)$ \\
\hline Expressive Function & .23862 & .04436 & -.72203 & -.12517 \\
\hline Instructional Function & .08017 & .16443 & -.88871 & .7835 \\
\hline Engagement Function & .36891 & .14153 & .38974 & .94434 \\
\hline Operational Function & .85644 & -.01031 & -.63881 & -.47115 \\
\hline Extraversion personality & -.49577 & .06487 & -.63315 & .3699 \\
\hline Agreeableness personality & -.44722 & .71215 & -.3446 & -.20118 \\
\hline Conscientiousness personality & -.33345 & .8763 & -.31507 & -.87386 \\
\hline Neuroticism personality & .5347 & .81334 & .07086 & .14295 \\
\hline Openness to Experience & -.58562 & -.66723 & .0637 & .40297
\end{tabular}

PST, Personal Style of the Therapist; BFI, Big Five Inventory. 
Table 4. Analysis of variance between clusters and the factors of Personal Style of the Therapist and Big Five Inventory (N=546).

\begin{tabular}{|c|c|c|c|c|c|c|c|}
\hline \multirow[t]{2}{*}{ Dimensions of PST and BFI } & \multirow[t]{2}{*}{ Cluster } & \multirow[t]{2}{*}{ M (SD) } & \multicolumn{2}{|c|}{ IC $95 \%$} & \multirow[t]{2}{*}{$F$} & \multirow[t]{2}{*}{$\mathbf{P}$} & \multirow[t]{2}{*}{$\eta^{2}$} \\
\hline & & & Inf. limit & Sup. limit & & & \\
\hline \multirow[t]{4}{*}{ Attentional Function } & 1 & $22.55(4.76)^{\mathrm{a}}$ & 21.77 & 23.34 & \multirow{4}{*}{85.52} & \multirow{4}{*}{.000} & \multirow{4}{*}{.321} \\
\hline & 2 & $18.28(5.05)^{\mathrm{ab}}$ & 17.48 & 19.10 & & & \\
\hline & 3 & $13.99(4.22)^{\mathrm{abc}}$ & 13.32 & 14.67 & & & \\
\hline & 4 & $17.33(4.32)^{\mathrm{ab}}$ & 16.47 & 18.2 & & & \\
\hline \multirow[t]{4}{*}{ Expressive Function } & 1 & $38.53(6.94)^{\mathrm{a}}$ & 37.40 & 39.68 & \multirow{4}{*}{99.28} & \multirow{4}{*}{.000} & \multirow{4}{*}{.355} \\
\hline & 2 & $37.86(7.87)^{\mathrm{b}}$ & 36.60 & 39.13 & & & \\
\hline & 3 & $28.33(7.07)^{a b c}$ & 27.21 & 29.47 & & & \\
\hline & 4 & $43.47(7.18)^{\mathrm{abc}}$ & 42.03 & 44.91 & & & \\
\hline \multirow[t]{4}{*}{ Instructional Function } & 1 & $31.72(5.79)^{\mathrm{a}}$ & 30.78 & 32.68 & \multirow{4}{*}{48.10} & \multirow{4}{*}{.000} & \multirow{4}{*}{.210} \\
\hline & 2 & $32.13(6.56)^{\mathrm{b}}$ & 31.08 & 33.19 & & & \\
\hline & 3 & $33.76(5,49)^{\mathrm{ac}}$ & 32.89 & 34.64 & & & \\
\hline & 4 & $24.98(5.39)^{\mathrm{abc}}$ & 23.91 & 26.07 & & & \\
\hline \multirow[t]{4}{*}{ Engagement Function } & 1 & $25.76(5.34)^{\mathrm{a}}$ & 24.88 & 26.64 & \multirow{4}{*}{42.51} & \multirow{4}{*}{.000} & \multirow{4}{*}{.190} \\
\hline & 2 & $23.39(5.65)^{\mathrm{ab}}$ & 22.48 & 24.30 & & & \\
\hline & 3 & $19.45(5.96)^{\mathrm{abc}}$ & 18.51 & 20.41 & & & \\
\hline & 4 & $26.4(5.57)^{\mathrm{bc}}$ & 25.29 & 27.52 & & & \\
\hline \multirow[t]{4}{*}{ Operational Function } & 1 & $27.65(5.70)^{\mathrm{a}}$ & 26.71 & 28.59 & & & \\
\hline & 2 & $22.38(6.30)^{\mathrm{ab}}$ & 21.37 & 23.40 & 8984 & 000 & 332 \\
\hline & 3 & $17.74(4.66)^{\mathrm{ab}}$ & 17.00 & 18.49 & & & \\
\hline & 4 & $19.49(4.75)^{\mathrm{ab}}$ & 18.54 & 20.45 & & & \\
\hline Extraversion & 1 & $26.92(4.56)^{\mathrm{a}}$ & 26.17 & 27.67 & & & \\
\hline & 2 & $32.99(3.71)^{\mathrm{ab}}$ & 32.40 & 33.59 & 5820 & 000 & 244 \\
\hline & 3 & $27.68(4.55)^{\mathrm{bc}}$ & 26.95 & 28.41 & & & \\
\hline & 4 & $30.26(4.8)^{\mathrm{abc}}$ & 29.30 & 31.23 & & & \\
\hline Agreeableness & 1 & $35.26(3.5)^{\mathrm{a}}$ & 34.69 & 35.84 & & & \\
\hline & 2 & $40.74(3.04)^{\mathrm{ab}}$ & 40.25 & 41.23 & 77.71 & 000 & 301 \\
\hline & 3 & $35.81(3.88)^{\mathrm{b}}$ & 35.21 & 36.42 & & & \\
\hline & 4 & $36.28(3.48)^{\mathrm{b}}$ & 35.59 & 36.98 & & & \\
\hline Conscientiousness & 1 & $35.31(4.25)^{\mathrm{a}}$ & 34.61 & 36.01 & & & \\
\hline & 2 & $40.92(3.33)^{\mathrm{ab}}$ & 40.39 & 41.46 & 9788 & 000 & 351 \\
\hline & 3 & $37.29(4.15)^{\mathrm{abc}}$ & 36.63 & 37.95 & & & \\
\hline & 4 & $32.66(4.05)^{\mathrm{abc}}$ & 31.86 & 33.48 & & & \\
\hline Neuroticism & 1 & $23.16(4.83)^{\mathrm{a}}$ & 22.37 & 23.97 & & & \\
\hline & 2 & $17.17(4.15)^{\mathrm{ab}}$ & 16.51 & 17.84 & 4622 & 000 & 204 \\
\hline & 3 & $20.81(4.22)^{\mathrm{ab}}$ & 20.14 & 21.49 & & & \\
\hline & 4 & $21.21(4.69)^{\mathrm{ab}}$ & 20.27 & 22.16 & & & \\
\hline Openness to Experience & 1 & $35.36(5.54)^{\mathrm{a}}$ & 34.46 & 36.28 & & & \\
\hline & 2 & $41.68(5.21)^{\mathrm{ab}}$ & 40.85 & 42.53 & 42.19 & .000 & .189 \\
\hline & 3 & $37.84(5.62)^{\mathrm{abc}}$ & 36.95 & 38.75 & & & \\
\hline & 4 & $41.28(5.11)^{\mathrm{ac}}$ & 40.26 & 42.31 & & & \\
\hline
\end{tabular}

The sub index (a, b c c) points out significant differences between the means in Bonferroni post hoc analysis $(\mathrm{P}<.05)$. PST, Personal Style of the Therapist; BFI, Big Five Inventory; M, Mean; SD, Standard deviation; IC, Interval of confidence. 
2014). Therapists tend to act in a variety of ways, as different studies using cluster analysis as a methodology have shown (Gonsalvez, Hamid, Savage, \& Livni, 2017; Kaur, Grover, \& Desai, 2015; Montaño-Fidalgo, Ruiz, Calero-Elvira, \& Froján-Parga, 2015). This study went beyond the PST construct, since a comprehensive assessment of therapist's personality was conducted, a variable noted by previous studies as being closely attached to the professional's work style (Boerebach et al., 2014; Chapman, Talbot, Tatman, \& Britton, 2009; Peter, Böbel, Hagl, Richter, \& Kazén, 2017).

Before performing the cluster analysis, the correlation between PST functions and BFI factor was studied. Previous studies have addressed this topic (Corbella-Santoma et al., 2007; Estrada-Aranda, 2014; Hermosa-Bosano, 2010), one of which used the same instruments as those in this paper (PST-Q and BFI) for Argentinian therapists (Genise, 2015; Genise \& García, 2016). However, the results from that research do not match any of the correlations found in this paper.

The PST technical functions (Castañeiras et al., 2008) have negative correlations with Conscientiousness (correlated with Attentional function) and Openness to Experience (correlated with Operative Function). It can be said that therapists' narrow-focused attention (Attentional Function) is associated with a lower level of Conscientiousness, which means they have low commitment to achieve their goals and they are more hedonistic. The preference for spontaneous interventions, on its part, seems to be related to the therapists' creativity.

The motivational and emotional aspects of the PST,
Expressive and Engagement Functions (Castañeiras et al., 2008) have multiple correlations. The therapist's emotional closeness (Expressive Function) has two correlations with Extraversion (positive correlation) and Conscientiousness (negative correlation), which means that while the emotional closeness with the patient tends to increase, it's related with personality characteristics as being more energetic and dynamic and having more inclination for a hedonistic attitude. The Engagement Function is positively related to therapist's emotional stability (Neuroticism), meaning that high commitment to the task and the patients could be harmful in terms of the therapist's mental health.

Finally, the Instructional Function positively correlated with Conscientiousness, so the therapist's preference for structured rules in psychotherapy may be associated with his or her determination.

Proceeding with the first aim, to describe therapists' profiles based on PST functions and personality dimensions, the four-cluster distribution was the most satisfactory solution in the cluster analysis.

Cluster 1 was characterized by the Attentional and Operational PST technical functions, partially like the directive group described by Fernández-Álvarez et al. (2017). When adding personality characteristics, Cluster 1 referred to therapists with lower emotional stability, who were reserved and lonely, more competitive and conservative. This cluster included most of the cognitive-behavioral, integrative, and systemic therapists. Due to the interaction between PST and BFI factors, this group was referred to as directive and vulnerable.

Table 5. Associations between clusters and theoretical approaches.

\begin{tabular}{|c|c|c|c|c|c|c|c|c|c|c|c|}
\hline & & Frequencies & & Clus & ster & & Total & $\chi^{2}$ & df & $\mathbf{P}$ & $\boldsymbol{V}$ \\
\hline & & percentages & 1 & 2 & 3 & 4 & & & & & \\
\hline Theoretical Approach & 1 & Observed & $33(50.76 \%)$ & $20(30.76 \%)$ & $5(7.69 \%)$ & $7(11 \%)$ & 65 & & & & \\
\hline & & Expected & $17.05(26.31 \%)$ & $18(27.69 \%)$ & $18.24(28.06 \%)$ & $11.68(12.46 \%)$ & 65 & & & & \\
\hline & 2 & Observed & $12(27.27 \%)$ & $8(18.18 \%)$ & $7(15.90 \%)$ & $17(38.63 \%)$ & 44 & & & & \\
\hline & & Expected & $11.54(26.22 \%)$ & $12.19(27.70 \%)$ & $12.35(28.06 \%)$ & $7.91(17.97 \%)$ & 44 & & & & \\
\hline & 3 & Observed & $55(31.79 \%)$ & $57(32.94 \%)$ & $30(17.34 \%)$ & $31(17.91 \%)$ & 173 & & & & \\
\hline & & Expected & $45.39(26.23 \%)$ & $47.93(27.20 \%)$ & $48.56(28.06 \%)$ & $31.1(17.97 \%)$ & 173 & & & & \\
\hline & 4 & Observed & $18(9.72 \%)$ & $41(22.16 \%)$ & $106(57.29 \%)$ & $20(10.81 \%)$ & 185 & 155.44 & 15 & .000 & .308 \\
\hline & & Expected & $48.54(26.23 \%)$ & $51.25(27.70 \%)$ & $51.93(28.07 \%)$ & $33.26(17.97 \%)$ & 185 & & & & \\
\hline & 5 & Observed & $19(33.33 \%)$ & $19(33.33 \%)$ & $3(5.26 \%)$ & $16(28.07 \%)$ & 57 & & & & \\
\hline & & Expected & $14.95(26.22 \%)$ & $15.79(27.70 \%)$ & $16(28.07 \%)$ & $10.24(17.96 \%)$ & 57 & & & & \\
\hline & 6 & Observed & $7(31.81 \%)$ & $6(27.27 \%)$ & $2(9.09 \%)$ & $7(31.81 \%)$ & 22 & & & & \\
\hline & & Expected & $5.8(26.36 \%)$ & $6.1(27.72 \%)$ & $6.2(28.18 \%)$ & $3.9(17.72 \%)$ & 22 & & & & \\
\hline Total & & Observed & $144(26.37 \%)$ & $151(27.65 \%)$ & $153(28.02 \%)$ & $98(17.94 \%)$ & 546 & & & & \\
\hline & & Expected & $144(26.37 \%)$ & $151(27.65 \%)$ & $153(28.02 \%)$ & $98(17.94 \%)$ & 546 & & & & \\
\hline
\end{tabular}

The theoretical orientation is in numbers: 1) Cognitive Behavioral Therapy; 2) Humanistic-Existential Gestalt Therapy; 3) Integrative Therapy; 4) Psychoanalysis; 5) Systemic therapy; 6) Other 
Cluster 4 presented the opposite, with therapists being what may be described as emotional. They gave importance to the affective part of their role, prioritizing emotional closeness and claiming a strong commitment to their work. These professionals were also described as flexible in their therapeutic setting and slightly hedonistic. Represented mostly by humanistic, existential and Gestalt therapists, this profile bears a partial resemblance to another cluster described in previous research (QuiñonesBergeret et al., 2010).

Cluster 3 showed the largest amount of polarities of PST, which pointed to these therapists' strong identification with their therapeutic style, but none with personality dimensions. These therapists' profile was characterized by their broad-focused attention, spontaneous interventions, low level of commitment to the patient (perhaps to establish some distance with their personal life) and distance in the therapeutic alliance. Additionally, they seemed to be highly structured when it came to establish the rules for the therapeutic setting. This last aspect (the Instructional Function) is the only one like one of the profiles described by Quiñones-Bergueret et al. (2010). This cluster was depicted as psychoanalytic as most of the professionals in the group claimed to belong to this theoretical orientation.
Cluster 2 was characterized by therapists with higher development (scores) of personality factors. Energetic, cooperative, committed, emotionally stable and creative, this group was described as proactive. The therapists in this group did not necessarily stand out for their professional qualities but for their personal ones. It is represented by integrative and systemic therapists.

It is noteworthy that personality is regarded as a central instrument of the therapist's work (Consoli \& Machado, 2004). It is even argued that therapists ultimately choose a given theoretical orientation according to their personality (Cariaga-Siracusa \& Casari, 2014; García \& Fernández-Álvarez, 2007; Opazo-Castro, 2001). A research study (Cariaga-Siracusa \& Casari, 2014) explored the relationship between personality and theoretical orientations in Psychology students using the BFI, where only significant differences in the dimension of Conscientiousness were found. In this study, the students of the Humanistic-Existential orientation displayed the highest values in this dimension, an opposite result to the one obtained in this paper.

Personality dimensions were seen to interact with PST functions when constructing different therapist profiles. In descending order, Cluster 2 (proactive) showed the highest number of personality characteristics, followed by

Table 6. Correlations between factors of Personal Style of the Therapist and Big Five Inventory with years of professional experience.

\begin{tabular}{|c|c|c|c|}
\hline & Dimensions of PST and BFI & & Years of professional experience \\
\hline \multirow[t]{10}{*}{ PST functions } & \multirow[t]{2}{*}{ Attentional } & $r$ & -.09 \\
\hline & & $\mathrm{P}$ & .02 \\
\hline & \multirow[t]{2}{*}{ Expressive } & $r$ & .03 \\
\hline & & $\mathrm{P}$ & .39 \\
\hline & \multirow[t]{2}{*}{ Instructional } & $r$ & .04 \\
\hline & & $\mathrm{P}$ & .26 \\
\hline & \multirow[t]{2}{*}{ Engagement } & $r$ & -.03 \\
\hline & & $\mathrm{P}$ & .46 \\
\hline & \multirow[t]{2}{*}{ Operational } & $r$ & -.01 \\
\hline & & $\mathrm{P}$ & .65 \\
\hline \multirow[t]{10}{*}{ Personality factors } & \multirow[t]{2}{*}{ Extraversion } & $r$ & .10 \\
\hline & & $\mathrm{P}$ & .01 \\
\hline & \multirow[t]{2}{*}{ Pleasantness } & $r$ & .10 \\
\hline & & $\mathrm{P}$ & .01 \\
\hline & \multirow[t]{2}{*}{ Conscientiousness } & $r$ & .17 \\
\hline & & $\mathrm{P}$ & .0008 \\
\hline & \multirow[t]{2}{*}{ Neuroticism } & $r$ & -.10 \\
\hline & & $\mathrm{P}$ & .01 \\
\hline & \multirow[t]{2}{*}{ Openness to Experience } & $r$ & .12 \\
\hline & & $\mathrm{P}$ & .003 \\
\hline
\end{tabular}

Numbers in bold and italics represent the statistically significant results. PST, Personal Style of the Therapist; BFI, Big Five Inventory. 
Cluster 1 (directive and vulnerable) and Cluster 4 (emotional); however, Cluster 3 (psychoanalytic) showed no interaction. In some cases, therapists were observed to be strongly identified with personality traits (Cluster 2), whereas in others, personality seemed to be of no relevance (Cluster 3).

The most striking cases were those in Clusters 1, 4 and 3. In the first one, certain risk factors emerged from the combination of personality dimensions, as the therapists in this group showed the lowest values in Extraversion, Openness to Experience and Agreeableness, and high scores in Neuroticism. The therapists labeled as emotional (Cluster 4) were given this name because of the prevalence of the Engagement and Expressive functions, but they were not consistent with the expected personality dimensions, such as Agreeableness, Extraversion or Conscientiousness. Finally, Cluster 3 was not characterized by any personality dimension, which may indicate the theoretical orientation variable had greater influence than the therapist's personality.

Regarding the second objective, to analyze if these profiles were related to the professionals' theoretical approach, data analysis showed a statistical association between therapists' profiles and theoretical orientation. Clusters 3 and 4 were the only ones where therapists were predominantly inclined to a given therapeutic orientation (psychoanalytic and humanistic-existential and Gestalt therapists, respectively), without an evident connection with personality dimensions in Cluster 3 , and a weak connection in Cluster 4.

Several characteristics have been noted as significant of psychoanalytic therapists in comparative studies of PST: broad-focused attention, increased emotional distance, lower levels of engagement, a preference for spontaneous interventions and rigidity when establishing the rules of the therapeutic setting (Castañeiras et al., 2006, 2008; Da Silva et al., 2006; Fernández-Álvarez, García, Castañeiras, \& Rial, 2005; Fernández-Álvarez, García, Lo Bianco, \& Corbella, 2000; Vázquez \& Gutiérrez, 2015). A single study (Silva-Palma \& Guedes-Gondim, 2016) found different results that showed these therapists as emotionally closer. This difference may be attributable to the sample being comprised of professionals from Brazil, not from Argentina. Beyond this information, most of the research reflects psychoanalytic therapists as having a clear profile in the PST (Vázquez \& Gutiérrez, 2015). The characteristics found in Cluster 3 coincide with those in the classical profile attributed to psychoanalysts in previous studies.

Cognitive-behavioral therapists, according to earlier studies, stand out in the technical functions of PST (Castañeiras et al., 2008): narrow-focused attention and a preference for planned interventions (Castañeiras et al., 2006, 2008; Da Silva et al., 2006; Fernández-Álvarez et al., 2000, 2005; Silva-Palma \& Guedes-Gondim, 2016; Vázquez \& Gutiérrez, 2015). Other studies, however, achieved differ- ent results, reporting these therapists as the main representatives of the motivational and emotional aspects of the PST (Expressive and Engagement Functions), featuring emotional closeness and higher commitment to the task (Castañeiras et al., 2006; Da Silva et al., 2006), as well as an inclination to establish the therapeutic setting in a flexible manner (Fernández-Álvarez et al., 2000). This type of therapists was represented (albeit not exclusively) in Cluster 1, which partially coincided with the first description: predominance of PST technical functions.

The third group studied in the PST literature is that of integrative therapists. The definition of integrative therapy currently covers four trends: theoretical integration, technical eclecticism, common factors, and assimilative integration (Norcross, 2005; Řiháček \& Roubal, 2017). However, when filling out the PST-Q, therapists need simply to indicate the theoretical orientation of their work. In the event of choosing an integrative orientation, no specification is required as to under which modalities such integration occurs in their practice. This has led to questions being raised concerning the essence of the integrative profile in the PST, since the information regarding the authors whom the integrative therapists rely on to define themselves as integrative is simply unknown, as it may well be built from a psychotherapy integrative theory or from an idiosyncratic assortment of theoretical orientations (Vázquez \& Gutiérrez, 2015).

Beyond this discussion, studies on PST about the integrative approach have succeeded in isolating certain distinctive features in these therapists: narrow-focused attention, a preference for spontaneous interventions, emotional closeness, and a high level of commitment to the task (Castañeiras et al., 2006, 2008; Fernández-Álvarez et al., 2005; Vázquez \& Gutiérrez, 2015). A contradiction emerges, however, in the Instructional function (related to the therapeutic setting), as some studies found these therapists to be more rigid (Fernández-Álvarez et al., 2000), and other studies found the opposite, i.e. more flexibility on their part (Vázquez \& Gutiérrez, 2015). Integrative therapists were mostly included in Clusters 1 and 2, but not exclusively. Previous studies coincide partially with the description of Cluster 1 (on the grounds of its relationship with the Attentional and Operational technical functions of the PST), while Cluster 2 showed no prevalence of any function of the PST.

Finally, the descriptions available in the literature of PST about systemic and humanistic-existential therapists are scarce. Systemic therapists have been described as emotionally close and flexible in the therapeutic setting (Fernández-Álvarez et al., 2005), having broader attention and a preference for spontaneous interventions (Quiñones, Ugarte, Ceric, García, \& Santibañez, 2019). Similarly, to the integrative therapists, they were distributed between Clusters 1 and 2. The characteristics derived from this paper do not coincide with those from previous research. The humanistic-existential and Gestalt therapists have 
been described as those with a lower level of engagement (Castañeiras et al., 2008) and a tendency towards spontaneous interventions (Silva-Palma \& Guedes-Gondim, 2016). In this respect, the first characteristic bears no similarity with previous research.

The last aim sought to establish the relationship between the years of clinical practice and the PST functions and personality factors. In the first case, only the Attentional function was related negatively, meaning that the narrow-focused tendency could be associated with fewer years of clinical practice. The same results were obtained in previous research (Castañeiras et al., 2006; Da Silva et al., 2006). However, other studies have not found significant outcomes when measuring these variables (Castañeiras et al., 2008; Moya-Cortés, 2015).

As for personality dimensions, all of them related positively to the years of professional practice, except for Neuroticism, meaning that the professional's experience is related to more dynamism, a willingness to help others, a general determined behavior, an inclination for esthetic values, and emotional stability. It seems that the professional's personality is a variable that is highly connected with the years of clinical practice, even more connected than with the PST themselves.

\section{Conclusions}

Our study shows that both the therapists' working styles and their personality dimensions ultimately shape different working profiles. Professionals differ from one another not only in the characteristics of their approach to the task, but also in the factors inherently connected with their personality style. It is possible to hypothesize a bidirectional relation: personality dimensions leading to the selection from a variety of theoretical orientations and, in turn, theoretical orientations influence personality traits. Determining which influence occurs first becomes complex. It could be argued that personality exercises the strongest influence, as it is developed earlier than any preference for a given orientation. This does not mean, however, that personality is an entirely stable structure or that it could not be influenced by a professional preference. A future challenge would be to explore and analyze which therapists' profiles succeed in constructing better therapeutic alliances or better outcomes; this information will then serve as a solid base to work in supervising personality aspects related to psychotherapy effectiveness.

\section{References}

Alonso, M., \& Klinar, D. (2016, November). Los psicólogos en Argentina. Relevamiento cuantitativo, 2015 [Psychologists in Argentina. Quantitative survey, 2015]. Paper presented at the VIII International Congress on Research and Professional Practice in Psychology, Buenos Aires, Argentina.

Anderson, T., Crowley, M. E. J., Himawan, L., Holmberg, J. K.,
\& Uhlin, B. D. (2016). Therapist facilitative interpersonal skills and training status: A randomized clinical trial on alliance and outcome. Psychotherapy Research, 26(5), 511529. doi: 10.1080/10503307.2015.1049671

Aron, A., \& Aron, E. (2001). Estadística para psicología [Statistics for psychology]. Buenos Aires: Prentice Hall.

Baldwin, S. A., \& Imel, Z. E. (2013). Therapist effects: findings and methods. In M. Lambert (Ed.), Bergin and Garfield's Handbook of Psychotherapy and Behavior Change (6th ed., pp. 258-296). New Jersey, EE.UU.: Wiley.

Balijepally, V., Mangalaraj, G., \& Iyengar, K. (2011). Are we wielding this hammer correctly? A reflective review of the application of cluster analysis in information systems research. Journal of the Association for Information Systems, 12(5), 375-413.

Beutler, L. E., Machado, P. P. P., \& Allstetter Neufeldt, S. (1994). Therapist variables. In A. Bergin \& S. Garfield (Eds.), Handbook of psychotherapy and behavior change (pp. 229269). New York: Wiley.

Boerebach, B. C. M., Scheepers, R. A., Van der Leeuw, R. M., Heineman, M. J., Arah, O. A., \& Lombarts, K. M. (2014). The impact of clinicians' personality and their interpersonal behaviors on the quality of patient care: a systematic review. International Journal for Quality in Health Care, 26(4), 426-481. doi: 10.1093/intqhe/mzu055

Botella, L., \& Corbella, S. (2005). Neurobiología de la autorregulación afectiva, patrones de apego y compatibilidad en la relación terapeuta-paciente [Neurobiology of affective self-regulation, attachment patterns and compatibility in the therapist-patient relationship]. Revista de Psicoterapia, 61, 77-104.

Cariaga-Siracusa, M. L., \& Casari, L. M. (2014). La incidencia de rasgos de personalidad en estudiantes avanzados en psicología hacia la elección de una línea teórica [The incidence of personality traits in advanced students in psychology towards the choice of a theoretical line]. Revista Psicogente. Órgano de difusión científica de la Universidad Simón Bolivar, 32(17), 379-396.

Casari, L., Ison, M., Albanesi, S., \& Maristany, M. (2017). Funciones del estilo personal del terapeuta en profesionales del campo de las adicciones [Functions of the personal style of the therapist in professionals in the field of addictions]. Pensamiento Psicológico, 15(1), 7-17. doi: 10.11144/Javerianacali.PPSI15-1.FEPT

Casari, L. M., Ison, M., \& Gómez, B. (2018). Estilo personal del terapeuta: estado actual (1998-2017) [Therapist's personal style: current status]. Revista Argentina de Clínica Psicológica, 27(3), 466-477. doi: 10.24205/03276716.2018. 1082.

Casari, L. M., Morán, V. E., \& Ison, M. S. (2017). Cuestionario de Estilo Personal del Terapeuta: análisis factorial confirmatorio de modelos rivales con psicoterapeutas argentinos [Personal Style Questionnaire of the Therapist: confirmatory factorial analysis of rival models with Argentine psychotherapists]. Psychologia: Avances de la Disciplina, 11(2), 6984. doi: 10.21500/19002386.2725

Castañeiras, C., García, F., Lo Bianco, J., \& Fernández-Álvarez, H. (2006). Modulating effect of experience and theoretical technical orientation on the Personal Style of the Therapist. Psychotherapy Research, 16(5), 587-593. doi: 10.1080/ 10503300600802867

Castañeiras, C., Ledesma, R., García, F., \& Fernández-Álvarez, H. (2008). Evaluación del estilo personal del terapeuta: pre- 
sentación de una versión abreviada del Cuestionario EPT-C [Evaluation of the therapist's personal style: presentation of an abbreviated version of the EPT-C Questionnaire]. Terapia Psicológica, 26(1), 5-13. doi: 10.4067/S0718-48082008000 100001

Castro-Solano, A. (2005). Técnicas de Evaluación psicológica en los ámbitos militares [Psychological assessment techniques in military settings]. Buenos Aires: Paidós.

Chapman, B. P., Talbot, N., Tatman, A. W., \& Britton, P. C. (2009). Personality traits and the Working Alliance in psychotherapy trainees: An organizing role for the five-factor model? Journal of Social and Clinical Psychology, 28(5), 577-596. doi: 10.1521/jscp.2009.28.5.577

Ciorbea, I., \& Nedelcea, C. (2012). The theoretical orientation shapes the personality of the psychotherapist? Procedia-Social and Behavioral Sciences, 46, 495-503. doi: 10.1016/j. sbspro.2012.05.149

Cohen, J. (1988). Statistical power analysis for the behavioral sciences (2nd ed.). New York: Lawrence Erlbaum Associates.

Consoli, A., \& Machado, P. (2004). Los psicoterapeutas, ¿nacen o se hacen? Las habilidades naturales y adquiridas de los psicoterapeutas: implicaciones para la selección, capacitación y desarrollo profesional [Are psychotherapists born or made? The natural and acquired skills of psychotherapists: implications for selection, training and professional development]. In H. Fernández Álvarez \& R. Opazo Castro (Comps.), La Integración en Psicoterapia [Integration in Psychotherapy] (pp. 385-451). Barcelona: Paidós.

Corbella, S., \& Botella, L. (2004). Investiigación en Psicoterapia: Procesos, resultados y factores comunes [Research in psychotherapy: process, results and common factors]. Madrid: Vision Net.

Corbella-Santoma, S., Botella, L., Fernández-Álvarez, H., Saúl, L., \& García, F. (2009). Developing the Therapist's Personal Style. Presented at the 40th International Meeting of the Society for Psychotherapy Research, Santiago de Chile, Chile.

Corbella-Santoma, S., Fernández-Álvarez, H., Botella, L., García, F., Lo Bianco, J., \& Canizzarro, A. (2007). Compatibility between Therapist's Personal Style and Patient's Personality. Presented at 38th Annual Meeting of S.P.R: Wisconsin, U.S.A.

Da Silva, M., Tellet, M., Fernández-Álvarez, H., \& García, F. (2006). Estilo pessoal do terapeuta: Dados preliminares da versão brasileira do EPT-Q [Personal style of the therapist: Preliminary data from the Brazilian version of the EFA-Q]. Revista Psico, 37(3), 241-247.

Del Re, A. C., Flückiger, C., Horvath, A. O., Symonds, D., \& Wampold, B. E. (2012). Therapist effects in the therapeutic alliance-outcome relationship: A restricted-maximum likelihood meta-analysis. Clinical Psychology Review, 32(7), 642-649. doi: 10.1016/j.cpr.2012.07.002

Dinger, U., Zimmermann, J., Masuhr, O., \& Spitzer, C. (2017). Therapist effects on outcome and alliance in inpatient psychotherapy: The contribution of patients' symptom severity. Psychotherapy, 54(2), 167-174. doi: 10.1037/pst0000059

Dolnicar, S. (2002). A review of unquestioned standards in using cluster analysis for data-driven market segmentation. $C D$ Conference Proceedings of the Australian and New Zealand Marketing Academy Conference 2002 (ANZMAC 2002). Deakin University, Melbourne.

Estrada-Aranda, B. (2014). Correlaciones entre el Estilo Personal del Terapeuta y Escalas Clínicas del MMPI-II [Corre- lations between the therapist's personal style and clinical scales of the MMPI-II]. Revista Argentina de Clinica Psicológica, 23(2), 153-162.

Everitt, B. S., Landau, S., Leese, M., \& Stahl, D. (2011). Cluster analysis (5th ed.). New York: John Wiley \& Sons.

Fernández-Álvarez, H., \& García, F. (1998). El estilo personal del terapeuta: Inventario para su evaluación [The Therapist's Personal Style: An inventory for evaluation]. In S. Gril, A. Ibañez, I. Mosca, \& P. L. R. Sousa (Eds.), Investigación en Psicoterapia [Research in psychotherapy] (pp. 76-84). Pelotas: Educat.

Fernández-Álvarez, H., García, F., Castañeiras, C., \& Rial, V. (2005). Normalización del Cuestionario de Evaluación sobre el Estilo Personal del Terapeuta (EPT) en una población de psicoterapeutas de Argentina [Normalization of the assessment questionnaire on the personal style of the therapist (PST) in a population of psychotherapists in Argentina]. Paper presented at XII Jornadas de Investigación de la Facultad de Psicología, Universidad de Buenos Aires. Buenos Aires, Argentina.

Fernández-Álvarez, H., García, F., Lo Bianco, J., \& Corbella, S. (2000). Estilos personales en terapeutas psicoanalíticos, cognitivos e integrativos [Personal styles in psychoanalytic, cognitive and integrative therapists]. Presented at the II Congresso Latinoamericano de Pesquisa em Psicoanalise e Psicoterapia. Gramada, Brasil.

Fernández-Alvarez, H., García, F., Lo Bianco, J., \& CorbellaSantoma, S. C. (2003). Assessment questionnaire on the personal style of the therapist PST-Q. Clinical Psychology \& Psychotherapy, 10(2), 116-125. doi: 10.1002/cpp.358

Fernández-Álvarez, H. M., García, F. S., \& Schreb, E. (1998). The research program at AIGLE. Journal of Clinical Psychology, 54(3), 343-359. doi: 10.1002/(SICI)10974679(199804)54:3<343::AID-JCLP5>3.0.CO;2-Q.

Fernández-Álvarez, J., Castañeiras, C., García, F., Gómez, B., \& Fernández-Álvarez, H. (2017). Investigando el estilo personal del terapeuta: Correspondencia entre las autodescripciones y la observación de jueces externos [Researching the personal style of the therapist: Correspondence between selfdescriptions and observation by external judges]. Revista de Psicopatología y Psicología Clínica, 22(3), 207-217. doi: 10.5944/rppc.vol.22.num.3.2017.18238

García, F., \& Fernández-Álvarez, H. (2007). Investigación empírica sobre el Estilo Personal del Terapeuta: una actualización [Empirical research on the Personal Style of the Therapist: an update]. Revista Argentina de Clínica Psicológica, XVI (II), 121-128.

Genise, G. (2015). Relación entre el estilo personal del terapeuta, estilo de apego y factores de personalidad del terapeuta [Relationship between therapist's personal style, attachment style, and therapist personality factors]. Psicodebate, 15(1), 9-22.

Genise, S., \& García, F. (2016). Estudio de correlación entre el $E P T$, estilo de apego adulto y factores de personalidad [Study of correlation between EFA, adult attachment style and personality factors]. Poster presented at the $2^{\circ}$ Congreso Latinoamericano para el Avance de la Ciencia Psicológica. Ciudad Autónoma de Buenos Aires, Argentina.

Gómez, B., Castañeiras, C., Curtarelli, A., Fraga Míguez, M., García, F., Maristany, M., \& Fernández-Álvarez, H. (2011). Personal Style of the Therapist (PST). Intra and inter therapist verbal behavior analysis. How do therapists ask questions? Poster presented at the 42nd Annual Meeting of the 
Society for Psychotherapy Research, Bern, Switzerland.

Gonsalvez, C. J., Hamid, G., Savage, N. M., \& Livni, D. (2017). The Supervision Evaluation and Supervisory Competence Scale: Psychometric Validation. Australian Psychologist, 52(2), 94-103. doi: 10.1111/ap.12269

Grzona, S., Muñoz, M., Casari, L., \& Videla, R. (2016). Estilo Personal del Terapeuta en estudiantes. Comparación prepost prácticas clínicas [Personal Style of Therapist in students. Pre-post clinical practices comparison]. Poster presented at $2^{\circ}$ Congreso Latinoamericano para el Avance de la Ciencia Psicológica. Buenos Aires, Argentina.

Heinonen, E. (2014). Therapists' Professional and Personal Characteristics as Predictors of Working Alliance and Outcome in Psychotherapy. Helsinki: National Institute for Health and Welfare, Research 123.

Heinonen, E., \& Orlinsky, D. E. (2013). Psychotherapists' personal identities, theoretical orientations, and professional relationships: Elective affinity and role adjustment as modes of congruence. Psychotherapy Research, 23(6), 718-731. doi: 10.1080/10503307.2013.814926

Hermosa-Bosano, C. A. (2010). Influencia de los Rasgos de Personalidad y el Estilo Personal del Terapeuta Aprendiz sobre las Percepciones de la Alianza Terapéutica [Influence of Personality Traits and the Personal Style of the Apprentice Therapist on the Perceptions of the Therapeutic Alliance]. Thesis of Licenciature in Clinical Psychology. Colegio de Artes Liberales, Universidad de San Francisco de Quito.

Hernández-Sampieri, R., Fernández-Collado, C., \& BaptistaLucio, C. B. (2014). Metodología de la investigación (6th ed.) [Research methodology]. México D.F.: Mc Graw-Hill Interamericana Editores.

John, O. E. (1990). The "Big Five" factor taxonomy: Dimensions of personality in the natural language and in questionnaires. In L. A. Pervin (Ed.), Handbook of personality theory and research (pp. 66-100). New York: Guilford Press.

Kaur, A., Grover, N., \& Desai, N. G. (2015). Therapeutic identity among clinical psychology professionals in India. Psychological Studies, 60(4), 402-406. doi: 10.1007/s12646015-0334-6

King, R. J., Orr, J. A., Poulsen, B., Giacomantonio, S. G., \& Haden, C. (2017). Understanding the therapist contribution to psychotherapy outcome: A meta-analytic approach. $A d$ ministration and Policy in Mental Health and Mental Health Services Research, 44(5), 664-680. doi: 10.1007/s10488016-0783-9

Lambert, M. J. (2013). The efficacy and the effectiveness of psychotherapy. In M. Lambert (Ed.), Bergin and Garfield's Handbook of Psychotherapy and Behavior Change (6th ed., pp. 169-217). New Jersey, EE.UU: Wiley.

Malik, M. L., Fleming, F., Penela, V., Harwood, M., Best, S., \& Beutler, L. (2002). Which therapist for which client? The interaction of therapist variation and client characteristics in affecting rates of change: An effectiveness study. Poster presented at Annual Meeting of the Society for Psychotherapy Research, San Francisco, U.S.A.

Manly, B. F. J. (2005). Multivariate Statistical Analysis. A Primer (3rd ed.). Boca Raton, Florida: Chapman \& Hall/CRC.

Mihai, D., \& Mocanu, M. (2015). Statistical considerations on the k-means algorithm. Annals of the University of CraiovaMathematics and Computer Science Series, 42(2), 365-373.

Miller, S. D., Hubble, M. A., Chow, D. L., \& Seidel, J. A. (2013).
The outcome of psychotherapy: yesterday, today, and tomorrow. Psychotherapy, 50(1), 88.97. doi: 10.1037/a0031097

Montaño-Fidalgo, M., Ruiz, E. M., Calero-Elvira, A., \& FrojánParga, M. X. (2015). Studying the therapeutic process by observing clinicians' in-session behaviour. Clinical Psychology \& Psychotherapy, 22(6), 533-545. doi: 10.1002/cpp. 1908

Moya-Cortés, L. (2015). Influencia del Estilo Personal del Terapeuta en la calidad de la alianza [Influence of the Therapist's Personal Style on the quality of the alliance]. Tesis de Lic. in Psicología. Pontificia Universida de Comillas de Madrid.

Niessen-Lie, H. A., Havik, O. E., Høglend, P. A., Monsen, J. T., \& Rønnestad, M. H. (2013). The contribution of the quality of therapists' personal lives to the development of the working alliance. Journal of Counseling Psychology, 60(4), 483495. doi: $10.1037 / \mathrm{a} 0033643$

Norcross, J. C. (2005). A primer on psychotherapy integration. In J. C. Norcross \& M. R. Goldfried (Eds.), Handbook of psychotherapy integration (pp. 3-23). New York: Oxford University Press.

Opazo Castro, R. (2001). Psicoterapia Integrativa. Una delimitación clínica [Integrative Psychotherapy. A clinical delimitation]. Santiago de Chile: Ediciones ICPSI.

Orlinsky, D. E., Grawe, K., \& Parks, B. K. (1994). Process and outcome in psychotherapy. In A. B. Bergin \& S. L. Garfield (Eds), Handbook of psychotherapy and behavior change (4th ed., pp. 270-376). New York: Wiley.

Parpottas, P., \& Draghi-Lorenz, R. (2015). Effects of therapists' attachment organization on the process and outcome of therapy: A review of the empirical literature. Counselling Psychology Review, 30(4), 44-56.

Peter, B., Böbel, E., Hagl, M., Richter, M., \& Kazén, M. (2017). Personality Styles of German-speaking psychotherapists differ from a norm, and male psychotherapists differ from their female colleagues. Frontiers in Psychology, 8, 840. doi: 10.3389/fpsyg.2017.00840

Prout, K. K., \& DeBerard, M. S. (2017). Therapist-Specific factors and psychotherapy outcomes of adult and youth clients seen in a psychology training clinic. Administration and Policy in Mental Health and Mental Health Services Research, 44(5), 681-690. doi: 10.1007/s10488-017-0798-x

Quiñones-Bergetet, A., Melipillán-Araneda, R., \& Ramírez Azócar, P. (2010). Estudio Psicométrico del Cuestionario de Estilo Personal del Terapeuta (EPT-C) en psicoterapeutas acreditados en Chile [Psychometric Study of the Personal Style Questionnaire of the Therapist (EPT-C) in accredited psychotherapists in Chile]. Revista Argentina de Clínica Psicológica, 19(3), 273-281.

Quiñones, A., Ugarte, C., Ceric, F., García, F., \& Santibañez, P. (2019). Estilo Personal del Terapeuta: comparación entre terapeutas cognitivos post-racionalistas y sistémicos [Personal Style of the Therapist: comparison between post-rational cognitive and systemic therapists]. Revista Argentina de Clínica Psicológica, 28(1), 48-55. doi: 10.24205/03276716. 2018.1054

Řiháček, T., \& Roubal, J. (2017). Personal therapeutic approach: Concept and implications. Journal of Psychotherapy Integration, 27(4), 548-560. doi: 10.1037/int0000082

Roos, J., \& Werbart, A. (2013). Therapist and relationship factors influencing dropout from individual psychotherapy: A literature review. Psychotherapy Research, 23(4), 394-418. doi: 10.1080/10503307.2013.775528 
Schiefele, A. K., Lutz, W., Barkham, M., Rubel, J., Böhnke, J., Delgadillo, J., ... Lambert, M. J. (2017). Reliability of therapist effects in practice-based psychotherapy research: A guide for the planning of future studies. Administration and Policy in Mental Health and Mental Health Services Research, 44(5), 598-613. doi: 10.1007/s10488-016-0736-3

Schöttke, H., Flückiger, C., Goldberg, S. B., Eversmann, J., \& Lange, J. (2017). Predicting psychotherapy outcome based on therapist interpersonal skills: A five-year longitudinal study of a therapist assessment protocol. Psychotherapy Research, 27(6), 642-652. doi: 10.1080/10503307.2015. 1125546

Silva-Palma, E. M., \& Guedes-Gondim, S. M. (2016). Questionário Reduzido do Estilo Pessoal do Terapeuta: evidências de validade [Reduced Therapist's Personal Style Questionnaire: evidence of validity]. Avalição psicológica, 15(3), 298-307. doi: 10.15689/ap.2016.1503.02

Steel, C., Macdonald, J., \& Schroder, T. (2018). A systematic review of the effect of therapists' internalized models of relationships on the quality of the therapeutic relationship. Journal of Clinical Psychology, 74(1), 5-42. doi: $10.1002 /$ jclp. 22484

Tschuschke, V., Crameri, A., Koehler, M., Berglar, J., Muth, K., Staczan, P., ... Koemeda-Lutz, M. (2015). The role of therapists' treatment adherence, professional experience, therapeutic alliance, and clients' severity of psychological problems: Prediction of treatment outcome in eight different psychotherapy approaches. Preliminary results of a naturalistic study. Psychotherapy Research, 25(4), 420-434. doi: 10.1080/10503307.2014.896055

Vázquez, L., \& Gutiérrez, M. (2015). Orientación teórico-técnica y EPT [Theoretical-technical orientation and EPT]. Revista Argentina de Clínica Psicológica, 24(2), 133-142.

Walsh, L. M., Roddy, M. K., Scott, K., Lewis, C. C., \& JensenDoss, A. (2018). A meta-analysis of the effect of therapist experience on outcomes for clients with internalizing disorders. Psychotherapy Research, 1-14. doi: 10.1080/ 10503307.2018.1469802

Wampold, B. E., \& Imel, Z. E. (2015). The great psychotherapy debate: The evidence for what makes psychotherapy work (2nd ed.) New York: Routledge.

Watson, J. C., Steckley, P. L., \& McMullen, E. J. (2014). The role of empathy in promoting change. Psychotherapy Research, 24(3), 286-298. doi: 10.1080/10503307.2013. 802823

Wedel, M., \& Kamakura, W. A. (2000) Market segmentation: conceptual and methodological foundations (2nd ed). Boston, New England: Kluwer Academic.

Zimmermann, D., Rubel, J., Page, A. C., \& Lutz, W. (2017). Therapist effects on and predictors of non-consensual dropout in psychotherapy. Clinical Psychology \& Psychotherapy, 24(2), 312-321. doi: 10.1002/cpp.2022 